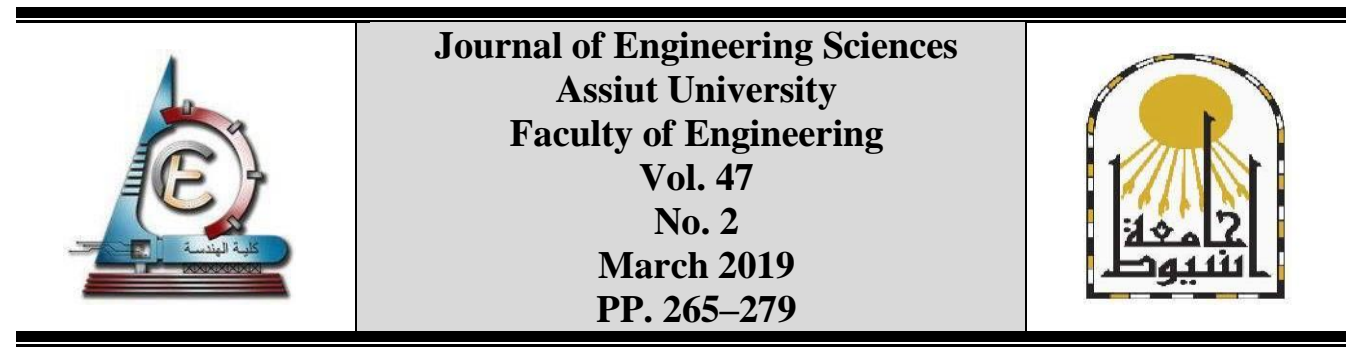

\title{
A SPATIAL EVALUATION OF THE DESIGN OF MIDDLE- INCOME HOUSING UNITS IN THE CITY OF ADEN: A CASE STUDY OF THE ENMAA RESIDENTIAL PROJECT.
}

\author{
Aqeil Ahmed Binthabet \\ Department of Architecture, College of Engineering, University of Aden
}

Received 5 March 2019; Accepted 29 March 2019

\begin{abstract}
Housing is an economic, social and cultural right that should be readily available in all inhabited areas, and this right has been enshrined as an international human right. Affordable housing should be safe and comfortable, meet all of the needs and wants of current and future residents, be able to be owned at the lowest cost, be of the best possible quality and be able to be lived in at the lowest possible cost. Housing units that meet a set minimum standard for living and are owned or rented by persons below a certain income level are considered to be affordable housing. Therefore, a unit meeting the requirements for affordable housing is the primary criterion for determining whether the housing is affordable or not. In some cases, housing costs may be affordable, but middle-income families are still unable to obtain the kind of housing that meets the minimum levels of quality that they require.

The purpose of this research paper was to study components of the housing units of middleincome real estate projects and analyse them to help in achieving the principles of cost reduction. The results can help interested proponents design residential units by considering a variety of elements, such as architectural spaces, sustainability, the number of occupants per unit and other aspects of housing. This study recommends increasing housing densities that reduce costs, developing flexible and straightforward architectural designs, lowering construction costs, increasing funding for housing and creating additional housing legislation.
\end{abstract}

Keywords: Affordable Housing, Middle-income Housing, Cost Reduction, Simplicity of Design, Sustainability, legislation.

\section{Introduction}

Residential and neighbourhood satisfaction is an important indicator of housing quality and conditions, and it affects an individual's quality of life [1]. The solution to the many housing problems requires revolutionary action against some of the most complex social issues known, such as poverty and adequate housing for low-income and middle-income families, which are the main concerns in many developing countries. For example, family accommodations consume a large portion of family income. In 2011, families that were affordably housed were able to spend nearly five times more on health care, a third more on food and twice as much on retirement savings than those who were not. [2]. 
In 1982, the United Nations General Assembly announced the development of an international year of shelter to help provide housing, but these efforts proved to be difficult in the years that followed because of worldwide socio-economic changes, dramatic increases in population and the need to improve the quality of dwellings for very many families. The availability of housing for a family is dependent upon their monetary spending capacity within a specified period, such as in monthly payments [3].

A standard of $30 \%$ of income is widely used as an accepted measure of housing affordability across the world [4]. Furthermore, an increase in low-rise housing styles with wide dimensions will complicate housing problems in the near future. Therefore, building designs should be reformulated based on a concept of affordable housing that considers economics, social changes and practical household requirements [5]. The changing political landscape from a capitalist system to socialist one can result in instability in the individual ownership of land, and housing cannot be considered as permanent personal property without the selling or issuance of a legal waiver as provided by Islamic law and statutes [6].

Middle-income families in Yemen have been facing difficulties in getting accommodation since the early 1990s due to domestic inflation, a decline in expatriate remittances, a rise in land prices and the cost of construction materials and a lack of subsidiary aid from the government [5]. In the early 20th century, Yemen's southern areas experimented with the establishment of housing units for low-income and middle-income residents in the suburbs of its principal cities. Despite a drastic attempt to determine the causes of the worsening problems in housing design, the attempt was not based on accurate information and did not get input from the community at any stage of decision making or planning process [7]. Similarly, the city of Aden experienced the construction of new residential units from 1967 until the unification of Yemen in 1990, reaching about 7,616 new housing units. In the Sheikh Ishaq areas of Al Ma'ala, 300 new houses were built; this time, however, it was evident that it was simply an effort to combat indiscriminate construction. Thus, to preserve the urban environment from deterioration and stop the spread of informal settlements, a general plan for the Greater Aden area (1982-2010) was developed for an area of 5,000 hectares [8]. Moreover, the Yemeni government developed several housing projects (reaching 7,305 new units) for middle-income people in the Sana'a and Hodeida governorates that were financed by World Bank loans. In addition, some lands have been distributed through housing associations (about 117 housing societies in the governorates) to subsidize middle-income employees of the state, most of which, however, have not been built on [9]. The Global Urban Observatory (GUO) was established in 1996 to provide support for the establishment and operation of urban observatories at regional and national levels, focusing on public observatories in cities. Urban observatories monitor data at the city, national or regional level to produce indicators that reflect the specific urban environments of the space for which they are responsible. One of the most critical goals for the GUO is to encourage interaction between government agencies, the private sector and civil society towards sustainable urban development [10].

\subsection{Statement of the housing problem}

A variety of designs for residential units have been used over the past few years by real estate companies providing housing for middle-income families in the city of Aden. Due to the modernity of these construction companies, it is necessary to analyse their design prototypes according to their architectural elements, including dimensions and intended 
Aqeil Ahmed Binthabet, A spatial evaluation of the design of middle-income housing units in .....

family size as well as if they achieve the principles of cost reduction. This analysis may help housing providers to serve the greatest number of families.

\subsection{Objectives of the research}

This research paper aims to analyse the components of the residential units provided by different construction companies for middle-income families. The results of this study will help these companies develop more efficient design solutions when working on the development of residential units.

\subsection{The limitations of the study}

The Enmaa Residential Project is located between Hassouh and Mansura directorates in the city of Aden, the economic capital of the Republic of Yemen. To the south, it overlooks the port of Aden and the directorates of Mualla and Attawahi, and to the west are the mountains of $\mathrm{Al}$ Buraiqeh. To the east are the Khormaksar directorate and the airport.

\subsection{Methodology}

This study used field research methodologies. In particular, it looked at the aforementioned villa prototypes and parameters as follows. First, the study focused on the area of the units, the number of rooms and their over-all functionality. Second, a social survey regarding household size and dwelling requirements was developed. Finally, the components of the design prototypes in regard to typical family size were analysed, and a statistical analysis was performed to determine the ratio of number of individual household occupants in proportion to the size and features of the housing units.

\section{Affordable housing}

Providing affordable housing is a progressive development priority for developing societies because sufficient housing is an essential factor for social stability and economic progress. The availability of affordable housing is an indicator of the growth and well-being of states and their citizens [6]. In a recent report, it was found that over one billion people in the world today live in inadequate housing, and an estimated 100 million live in conditions classified as homeless [11]. Therefore, affordable housing can be defined based on its economic, humanitarian and social aspects. Hence, according to the United Nations Human Settlements Commission, providing affordable housing still requires many further solutions, innovations and studies. Some definitions of the concept of affordable housing are as follows:

'Affordability' is an easy concept to grasp in general, but it can be hard to pin down in practice, especially in terms of the changing circumstances of individuals and households [12]. 'Affordable housing' is housing that would not put the buyer into mortgage stress [13].

Households with high incomes can spend a greater proportion of their income on housing and still have sufficient money to spend on other things. Therefore, it is not surprising that some commentators who have used a fixed benchmark for housing stress, such as housing repayments exceeding $30 \%$ of income, are finding that more and more households exceed the benchmark [14]. Adequate dwellings are those that achieve the necessary interests of individuals and their families and meet their minimum requirements for shelter at a reasonable cost commensurate with their income in the present and foreseeable future [6]. Affordable housing has been used as an alternative to terms such as 'public', 'social' or 'low and middle cost' housing. More problematically, affordability 
manifests differently by household type; that is, through the employment, transport, health and other consumption trade-offs made by single people, single parents or couples with children as they adapt to their circumstances of high housing costs and/or low income [15]. Housing that is appropriate to the needs of low to moderate income households is priced so that these incomes are sufficient enough to also meet other essential basic living costs [16].

\subsection{Factors affecting affordable housing}

The problem of housing affordability is easily stated: middle-income families are unable to afford the housing that can satisfy the required minimum quality for their households. Long-term affordability problems involve households that for the foreseeable future and for whatever cause, will be unlikely to have an income allowing them to purchase appropriate housing. Short-term affordability problems concern households that have an average income that over time is sufficient to purchase appropriate housing on the private market but who face short-term fluctuations in income that precipitate housing stress or crises [17]. Critical factors affecting the supply of housing include the following: (a) the availability and cost of land, (b) the availability of infrastructure, including the supply of essential services (roads, sewerage, drinking water, etc.), (c) regional development policies and regulations that address environmental concerns, for example the Resource Management Act, natural hazards, changes in development levies imposed by local authorities and government interventions (e.g. those aimed at improving the sustainability of the housing stock and regulatory statements in general), (d) the availability of financing at an affordable price and for different ownership structures such as multiple-owner land and (f) the performance and efficiency of the building and construction sector, including the length of time it takes the building industry to adjust to the changing demand for housing. The construction industry everywhere faces problems and challenges. However, in developing countries, these difficulties and challenges are present alongside a general situation of socio-economic stress, chronic resource shortages, institutional weaknesses and a general inability to deal with the key issues [18]. Table 1 shows the main factors affecting housing affordability [19].

\subsection{Middle-income housing}

Housing affordability can be assessed only if there is a comparison of income. However, analysts often use reference to house prices, rents, or non-income increases to describe housing affordability. Prices are not an indicator of affordability if they are not compared to income but have only a narrative value. House price trends or rents are not indicative of affordability without income comparison. Housing affordability is not a new issue among the middle-income households over the last decades. With the continuous increase in property price due to rapid economic growth, it will give a high struggle for the middle-income households to own an affordable house [20]. 
Aqeil Ahmed Binthabet, A spatial evaluation of the design of middle-income housing units in .....

Table 1.

Factors Affecting Housing Affordability [19].

\begin{tabular}{|c|c|c|c|c|}
\hline \multicolumn{5}{|c|}{ Factors Affecting Housing Affordability } \\
\hline Project Land & $\begin{array}{l}\text { Cost of Materials } \\
\text { Used }\end{array}$ & $\begin{array}{l}\text { Cost of Finishing } \\
\text { Work }\end{array}$ & $\begin{array}{l}\text { Construction } \\
\text { Methods Used }\end{array}$ & $\begin{array}{l}\text { External Factors } \\
\text { Influencing Cost of } \\
\text { Project Construction }\end{array}$ \\
\hline Cost of project land & Building with stone & Building formwork & $\begin{array}{l}\text { Traditional } \\
\text { methods (load } \\
\text { bearing walls) }\end{array}$ & $\begin{array}{l}\text { Materials available } \\
\text { on local market }\end{array}$ \\
\hline $\begin{array}{l}\text { Distance between } \\
\text { project location and } \\
\text { services and } \\
\text { transportation }\end{array}$ & $\begin{array}{l}\text { Building with red } \\
\text { brick }\end{array}$ & $\begin{array}{l}\text { Preparing } \\
\text { reinforced concrete }\end{array}$ & Concrete frames & $\begin{array}{l}\text { Tools and equipment } \\
\text { available on local } \\
\text { market }\end{array}$ \\
\hline $\begin{array}{l}\text { Distance between } \\
\text { project location and } \\
\text { employment area }\end{array}$ & $\begin{array}{l}\text { Building with local } \\
\text { brick (Yagoor) }\end{array}$ & Plastering & $\begin{array}{l}\text { External load } \\
\text { bearing walls and } \\
\text { central columns }\end{array}$ & Political conditions \\
\hline Land topography & $\begin{array}{l}\text { Building with } \\
\text { concrete blocks }\end{array}$ & Painting & $\begin{array}{l}\text { New technology } \\
\text { and industrialized } \\
\text { building systems } \\
\text { (IBS) }\end{array}$ & $\begin{array}{l}\text { Economic conditions } \\
\text { and currency value } \\
\text { and exchange rates }\end{array}$ \\
\hline & Cement & Tiling & & $\begin{array}{l}\text { Transportation and } \\
\text { fuel costs }\end{array}$ \\
\hline & $\begin{array}{l}\text { Steel for reinforced } \\
\text { concrete }\end{array}$ & $\begin{array}{l}\text { Doors and } \\
\text { windows }\end{array}$ & & Security conditions \\
\hline & & $\begin{array}{l}\text { Plumbing system } \\
\text { and requirements }\end{array}$ & & $\begin{array}{l}\text { Established } \\
\text { regulations and laws }\end{array}$ \\
\hline & & $\begin{array}{l}\text { Electrical system } \\
\text { and requirements }\end{array}$ & & $\begin{array}{l}\text { Administrative } \\
\text { procedures and } \\
\text { licensing }\end{array}$ \\
\hline & & & & Project designs \\
\hline & & & & $\begin{array}{l}\text { Project construction } \\
\text { supervision }\end{array}$ \\
\hline & & & & Executor contractors \\
\hline
\end{tabular}

Middle-income housing affordability is important, because affordable access to quality housing has been pivotal to the democratization of prosperity that occurred in the last century in most high-income nations. Normally, the competitive market has provided middle-income housing without the need for subsidies. Middle-income is different from low - income housing, which relies on public subsidies to serve the needs of households unable to afford the house prices or rents prevailing on the open market. Focusing on middle-income does not indicate a lesser interest in low-income housing, because subsidy eligibility requirements are tied to house prices. Better housing affordability translates into fewer households seeking housing subsidies through affordable housing programs (and less public expense).There are two principal dimensions of middle-income housing affordability-between housing markets and within individual market over time [21].

\subsubsection{Factors affecting middle-income housing}

Housing affordability among low-income and middle-income household is the main issue in developed and developing countries. The housing affordability level among middleincome households are affected by various factors, which are number of working adults in a 
household, age, health status, education level, types of occupation, housing expenses, house prices, household income, mortgage, housing loan and difficult to get housing loan.

In other ways these factors can be described : Non-monetary factors that affect the housing affordability among middle-income household are number of working adults available in a household, age, health status, education level, housing expenses and type of occupation [22]. While monetary factors that affect the housing affordability among middle-income household are housing expenses, house prices, household income, mortgage, housing loan and difficulty to get housing loan [23].

\subsection{Housing real estate}

Real estate is defined as a property comprised of land and all that is permanent connected to it and that cannot be moved without damage, such as buildings and trees. Local laws in each country determine the basis for distinguishing property from movables. Property is a legal concept encompassing all of the interests, rights and benefits associated with the right of ownership. Accordingly, property rights confer upon the owner specific interests and benefits of ownership, including the actual ownership of the real estate property and the rights associated with the rights package, such as the right to the disposal of the property and to sell or lease. Residential real estate is defined as a real estate development for the purpose of housing. Some development projects use subdivisions, where the land is divided into small plots and residential units are built on each plot. These units are easily affected by the development of adjacent areas [24].

According to the Saudi Commission for Accredited Residents, there are four types of factors that influence property demand. The first are social factors, which are related to society and the traits of a population, for example social trends, age distribution, the percentage of married people, cultural factors, individual tastes and the population growth rate. Second are economic factors, which are related to income levels, the state of the economy, local and regional economic trends and the costs of real estate financing affecting the demand side. Third are spatial and environmental factors, which are related to location, area, appearance, climate, the local environment and real estate development, all of which can increase or decrease demand for a property. Fourth are government factors, which are related to government decisions, regulations, laws and incentives for the real estate industry, including the monitoring the planning and development of real estate?

A developer begins by choosing a location in light of the geographical area and by taking into consideration a range of different factors that reflect the economic and social traits of the area as well as the availability of a means of transport [25]. The more transportation that is available, the more attraction there is to a region and, conversely, of the population. The developer will then begin to design an appropriate property in light of different regulations, including those imposed by municipalities to regulate buildings, until the designs are approved by the authorities and the required permits are obtained to start the project.

There are a variety of housing concepts, and it is possible to classify housing according to different characteristics. Housing policy is related to state intervention in the housing market [26]. The most common types of real estate in the Arab region are penthouses, apartments (duplex apartments, triplex apartments and studios), townhouses and independent villas (independent units with a wide garden and a special gate for a wall that surrounds on all sides). Features that all residential styles include are a kitchen, reception 
Aqeil Ahmed Binthabet, A spatial evaluation of the design of middle-income housing units in .....

room, living room, bedrooms and bathrooms, and they usually consist of two or three floors above each other [27].

Governmental and private institutions establish the primary legislation and regulations that govern their respective projects under specific parameters based on the nature and circumstances of each project. They implement controls during all stages of project development until completion of the project. The role of private sector banks and other organizations varies from the full to partial financing of projects that are readily available to all citizens. In the case of large-scale projects, the role of the developer extends from the private sector and includes overseeing sites and the needed facilities [6].

Under the public sector, the public middle-cost housing programmers are undertaken by the state and federal governments with the supervision and monitoring of the Ministry of Housing and Local Government. The governments are involved in the implementation of Public Housing programmers, Housing in Land and Regional Development Authority area, Government and Institutional Quarters, State Economic Development Corporation. Private sector housing consists of private developers, co-operative societies and individual or group of individuals [1].

\section{Case study: Enmaa residential project}

The company is deemed an extraordinary delivery in time scale, it is established on April 5th, 2004 but what it had accomplished makes it a leader in building construction field in Yemen. The company had constructed residential Enma city at Kabota that consist of 66 building containing 684 flat and 44 commercial store of different area. All the essential services were added to it such as electricity, water, sewerage, roads, lighting and greenery land escapes as a relieving areas. There are five options of villa specifications that has been approved for Enma's Residential villa, Abu Harbah. Two Storeys villa and excellent finishing attached (Deluxe),) Two storeys villa and very good finishing. Two storeys and attached structure. Two storey and attached structure villa with very good finishing and one storey villa structure (various types of storeys were built and finished for various middle-income families). The designs of the prototypes of the villas were of two different dimension types: one with a surface area of $16 \times 18\left(288 \mathrm{~m}^{2}\right)$, with 20 units built of two different prototype designs, and another with a surface area 15 x $16\left(240 \mathrm{~m}^{2}\right)$, with 76 units built of two different prototype designs (see Figures 1-16) [28].

Diagram of the Main Site of Enmaa Residential City, Abu Harba [28]. 

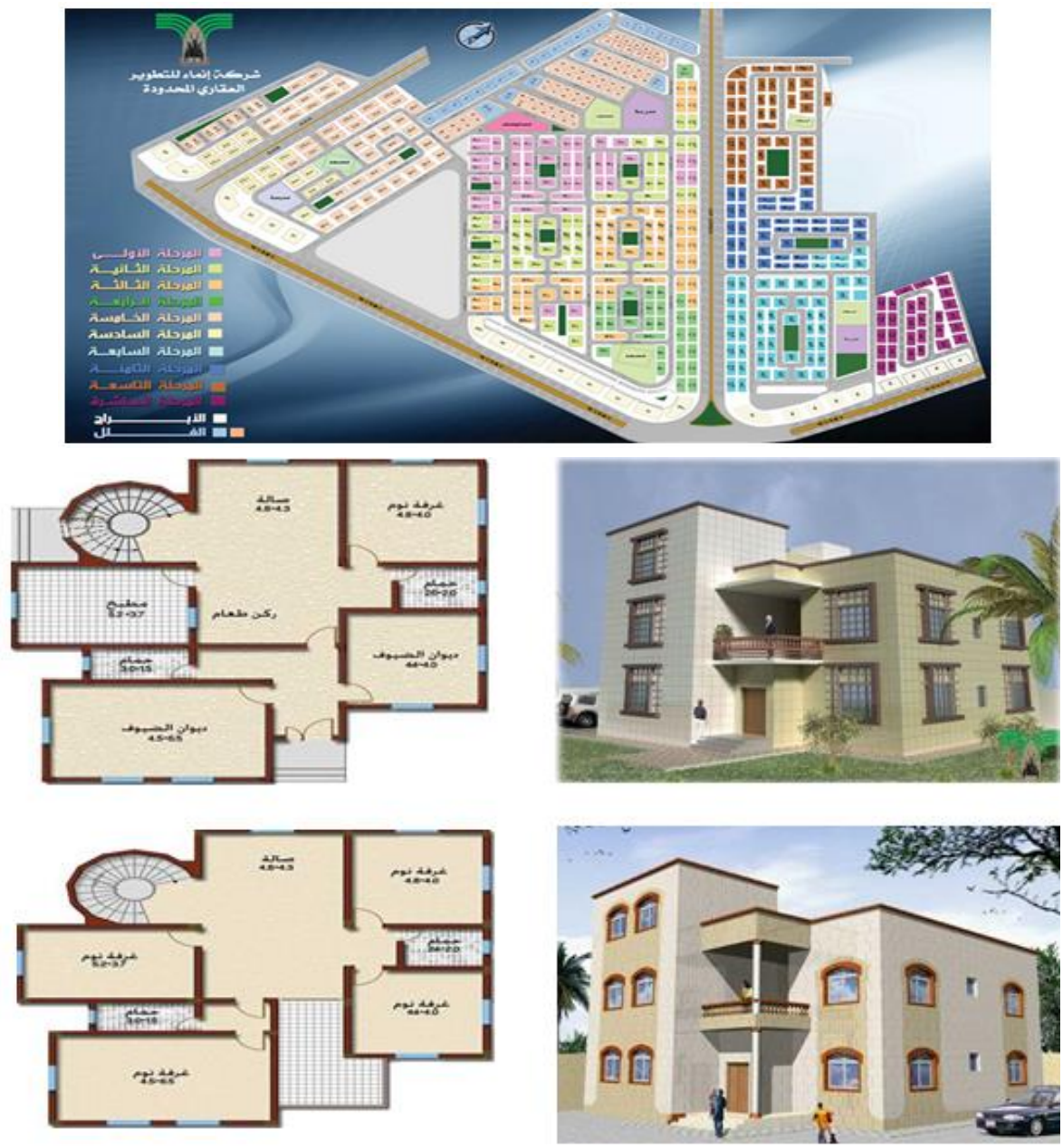

Figs. 5, 6, 7 \& 8. Unit B [28]
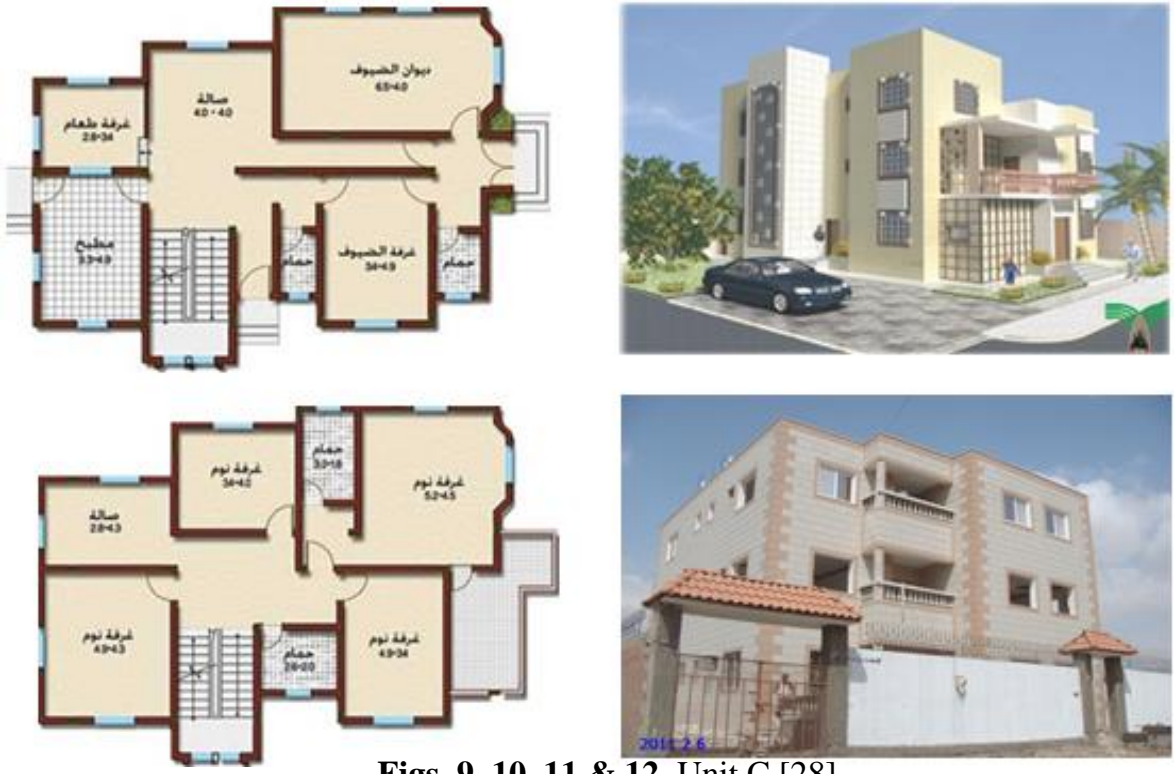

Figs. 9, 10, $11 \&$ 12. Unit C [28]. 

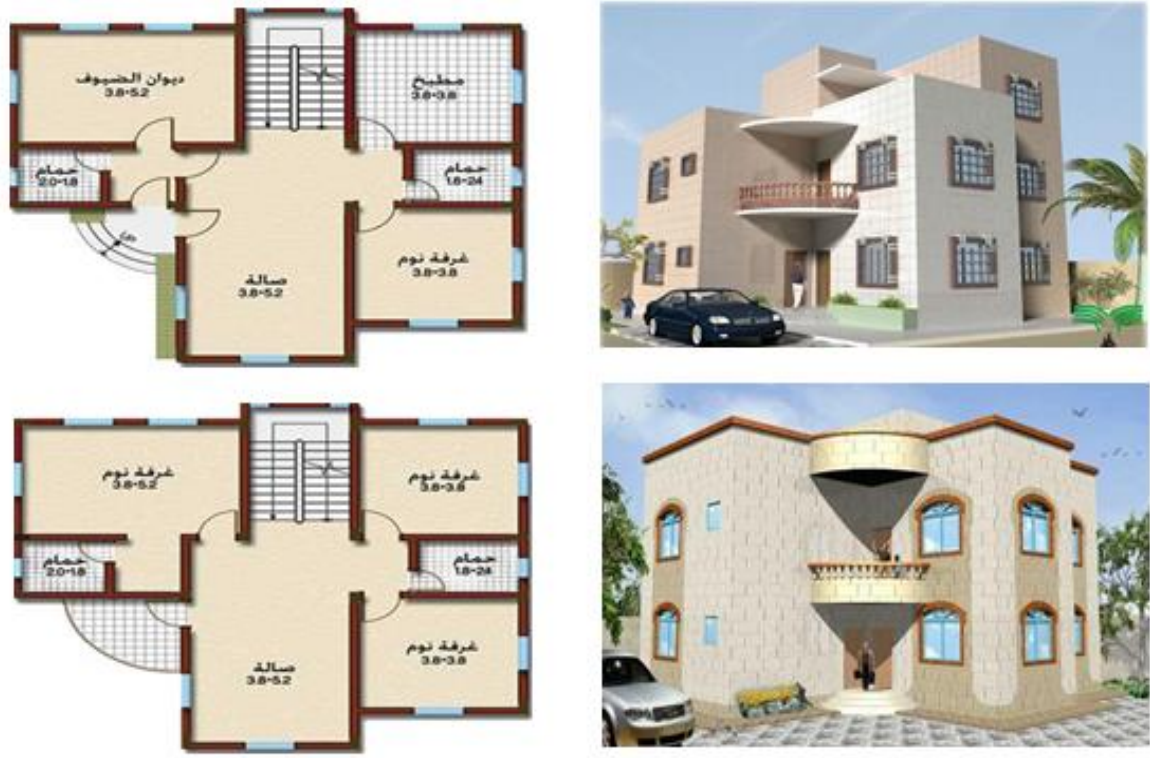

Figs. 13, 14, 15 \& 16. Unit D [28]

\section{Analytical study}

A field study was conducted on-site for the identification of the architectural characteristics of the housing prototypes and included a random distribution of the villas used in this project. The sample consisted of four prototypes designated as units A, B, C and $\mathrm{D}$. The defining characteristics were the areas that were determined to be either allocated for movement or non-specific use or those areas that were considered as essential parts of the architectural space and their proportions in the general area of the housing unit.

Then, the study sought to discover the number of people living in the residential project, the average number of family members per unit and the cost of each type of unit. Finally, the field study calculated the average housing area $\left(54.5 \mathrm{~m}^{2}\right)$ per occupant, and determined the average total area of all the different housing unit types. In regards to population density, the average number of people per dwelling was 7.1, and the cost for high-quality finishing of a two-floor flat was $\$ 558.62$ per $\mathrm{m}^{2}$, while lower-quality finishing cost about $\$ 501.18$ per $\mathrm{m}^{2}$ (see Table 2). There is a comparison with another project in the city of Mukalla shown in Table3 and in Figures 17-22 [29].
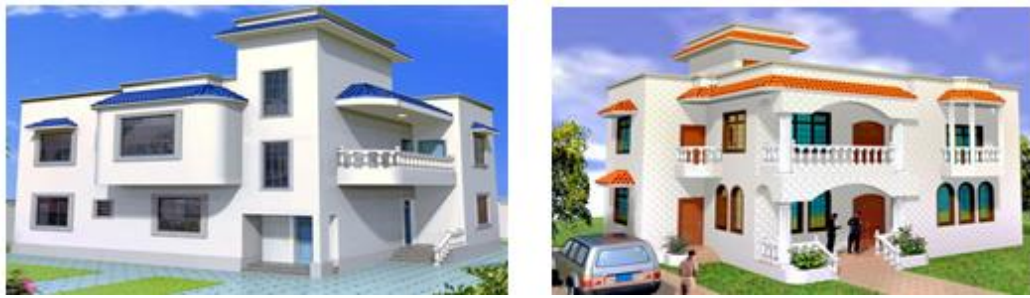

Figs. $17 \&$ 18. Units A and B project in the city of Mukalla [29] 

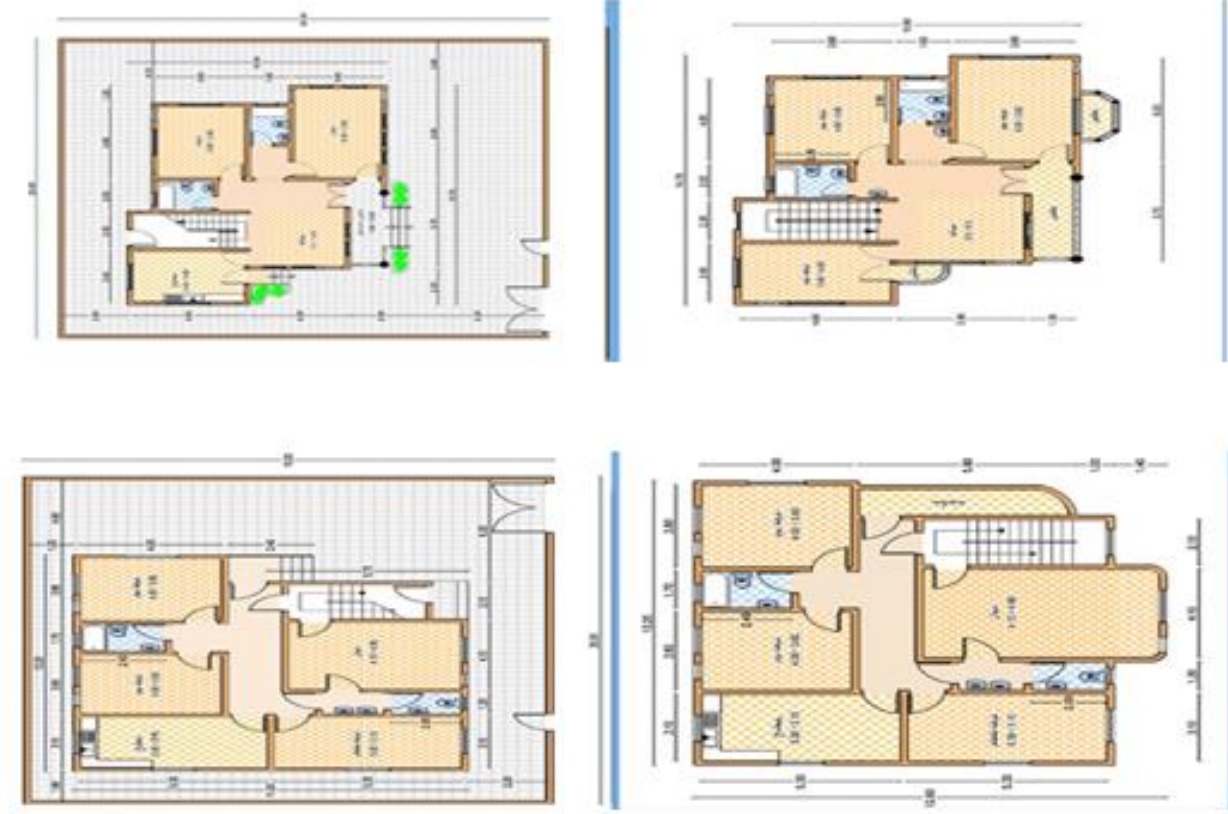

Figs. 19, 20, $21 \&$ 22. Units A Plan project in the city of Mukalla [29]

Consequently, it is clear that the units provide one room per 2.93 persons with a floor area of $20.82 \mathrm{~m}^{2}$; one bathroom per 3 persons and an overall allocation of $35.09 \mathrm{~m}^{2}$ floor area to each member of the family occupying a unit (see Table 5). It is important to remember that housing standards set the qualitative scale to meet housing needs. Furthermore, housing standards are one set of criteria that determines the housing goals of housing policy. Another consideration is an appropriate quality of housing that is in line with the socio-economic and technological development being experienced by a country. Design standards alone play a prominent role in housing policies by balancing the following two main factors that affect the definition of the area allocated for housing.

The first factor is the economic aspect of housing provision; the second factor is the increase in the dwelling spaces to address the needs and desires of the distinct inhabitants. Finally, to give an overview on an average household size, a Saudi family, for example, ranges from 6 to 8 persons (parents and four/six children) according to the population statistics prepared by the Department of Statistics [30] (as shown in Table 4).

Table 2.

Project Averages [Researcher]

\begin{tabular}{|c|c|c|}
\hline & \multicolumn{2}{|c|}{ Average } \\
\hline People/unit & \multicolumn{2}{|c|}{7.1} \\
\hline Person/m $/ \mathrm{m}^{2}$ & \multicolumn{2}{|c|}{54.5} \\
\hline Finished & $\begin{array}{c}\text { One } \\
\text { floor }\end{array}$ & $\begin{array}{c}\text { Two floors } \\
\text { Annex house }\end{array}$ \\
\hline Excellent & - & $\$ 558.62$ \\
\hline Very good & $\$ 898.95$ & $\$ 501.18$ \\
\hline Structures & $\$ 667.61$ & $\$ 335.85$ \\
\hline
\end{tabular}

Table 3.

Project Averages in Mukalla [Researcher]

\begin{tabular}{|l|c|c|}
\hline & \multicolumn{2}{|c|}{ Average } \\
\hline Finished & One floor & $\begin{array}{c}\text { Two floors } \\
\text { Annex House }\end{array}$ \\
\hline Very good & $\$ 474$ & $\$ 455$ \\
\hline Structures & $\$ 255$ & $\$ 251$ \\
\hline
\end{tabular}


Aqeil Ahmed Binthabet, A spatial evaluation of the design of middle-income housing units in .....

Table 4.

Area of Housing Elements [30]

\begin{tabular}{|c|c|c|}
\hline Housing Element & $\begin{array}{c}\text { Length and } \\
\text { width } \\
(\mathrm{m})\end{array}$ & $\begin{array}{c}\text { Area } \\
\left(\mathrm{m}^{2}\right)\end{array}$ \\
\hline Master bedroom & $4 \times 6$ & 24 \\
\hline $\begin{array}{c}\text { Bedrooms for } \\
\text { children }\end{array}$ & $5 \times 4 \times 3$ & 60 \\
\hline Living room & $5 \times 6$ & 30 \\
\hline Guest room & $6 \times 4$ & 24 \\
\hline Dining room & $5 \times 4$ & 20 \\
\hline Kitchen & $4 \times 4$ & 16 \\
\hline Bath and toilet & $4 \times 2.8 \times 1.8$ & 20 \\
\hline Roads and entrances & $7 \%$ & 15 \\
\hline Services & $2.5 \times 4$ & 10 \\
\hline Buildings & $5 \%$ & 11 \\
\hline Total & - & 230 \\
\hline
\end{tabular}

Table 5.

Average Area and Features per Person [Researcher]

\begin{tabular}{|c|c|c|c|c|c|c|c|c|c|c|}
\hline \multirow[b]{3}{*}{ Element } & \multicolumn{10}{|c|}{ Residential Unit Prototypes } \\
\hline & \multicolumn{5}{|c|}{ Number } & \multicolumn{3}{|c|}{ Area } & \multicolumn{2}{|c|}{ Person } \\
\hline & Average & Lowest & Highest & $\begin{array}{l}\text { Area } \\
\left(\mathrm{m}^{2}\right)\end{array}$ & $\begin{array}{l}\text { Area } \\
(\%)\end{array}$ & Average & lowest & Highest & $\begin{array}{l}\text { Person } \\
/ \mathrm{m}^{2}\end{array}$ & $\begin{array}{l}\text { Person/ } \\
\text { Element }\end{array}$ \\
\hline Rooms & 10.25 & 11 & 8 & 212.05 & 58.85 & 20.82 & 12.4 & 29.25 & 2.975 & 1.45 \\
\hline Kitchen & 1 & 1 & 1 & 15.22 & 4.24 & 15.22 & 11.2 & 19.24 & & \\
\hline Bathrooms & 5 & 5 & 5 & 21.9 & 6.07 & 4.68 & 3.6 & 5.76 & 3.08 & 1.42 \\
\hline & & & & 249.17 & 67.77 & & & & 35.09 & \\
\hline Accompanying & & & & 31.6 & 8.77 & & & & 4.45 & \\
\hline $\begin{array}{l}\text { Total Area of } \\
\text { Items }\end{array}$ & & & & 280.77 & 76.54 & & & & & \\
\hline $\begin{array}{l}\text { Motion and } \\
\text { Functional } \\
\text { Defined }\end{array}$ & & & & 79.53 & 23.46 & 81.75 & 73.97 & 88.58 & & \\
\hline Building Area & & & & 360.3 & 100 & & & & & \\
\hline
\end{tabular}

\section{Conclusion and recommendations}

\subsection{Conclusion}

This study has considered the concept of 'affordable housing' for middle-income families and may help those concerned with the design of housing units to consider more effectively the required housing elements, sizes of architectural spaces and number occupants per unit commensurate with the space required by individuals. Governments face challenges from a lack of assistance from real estate banks and the private sector. Restrictions such as insufficient budget allocations for middle-income projects as well as lack of proper housing feasibility studies contribute to a lack of development in the housing sector, thereby reducing the amount of housing construction and causing an increase in the cost of housing units.

The reduction in the number of areas developed for housing, complexity of the architectural spaces and cost of building materials are all considered to be primary factors affecting affordable housing. Therefore, reducing the number of rooms, their dimensions, 
the areas allocated for movement and the locations that are not defined as functional will contribute to cost-cutting for each housing unit. Thus, doing this would help to achieve the hypothesis of this research that considers the requirements for family housing as well as related economic and social variables.

\subsection{Recommendations}

In conclusion, governments should do the following:

- Substantiate the concepts and designs for affordable housing (middle-income housing) as a protocol among experts, decision-makers, architectural colleges and the private sector, taking advantage of the experiences from previous design stages and finding government support programs for future projects.

- Establish a database system and housing policy that will help new housing plans through the formation of a Higher Council for Housing and Urban Development, which will include institutions related to housing, urban planning, infrastructure services, financial institutions, the private sector and civil society organizations.

- Developing scientific research in the field of construction and housing through the establishment of a building and housing research center or association, which is associated with regional and international bodies, contributing to simple building techniques, raising the efficiency of planning and designing residential units and reducing their cost.

- Adopt the principles of 'housing densities' by increasing the number of residential units and the multiplicity of spaces and sizes, providing a more extensive range of design options that are commensurate with families within the middle-income bracket.

- Develop simple architectural designs, flexible architectural spaces and sustainable urban development (by ensuring that future housing policies are appropriate for all.

- Prepare engineering references (codes) for the technical and engineering standards of project designs to assist work studies, models, supervision and contract management.

- Implement training and qualification programs for designers, supervisors, implementers and management bodies to provide them with the necessary expertise in the field of housing policies, strategies and the management of middle-income housing projects.

- Increase the contribution of the government in budgetary allocations to projects providing adequate housing, and infrastructure, creating investment opportunities in housing, and take into account the detailed considerations for each project within the controls determined by the local government.

- Assist banks and public and private financial institutions in contributing to the financing of affordable housing programs, providing sources of finance for infrastructure services in residential areas and restructuring the Housing Credit Bank to play a useful role in a housing policy.

- Prepare legislation on the regulation of housing activity and the adoption of strategies and regulations to help investment in housing and take the necessary measures to combat land speculation.

\section{REFERENCES}

[1] Abd Ghani S., 2008. Neighbourhood Factors In Private Low-Cost Housing In Malaysia, A Journal for the Study of Human Settlements, Habitat International, Vol. 32, pp. 485-493.

[2] The State of the Nation's Housing, 2013. Impact of Affordable Housing on Families and Communities: A REVIEW OF THE EVIDENCE BASE, Joint Center for Housing Studies of Harvard University. 
Aqeil Ahmed Binthabet, A spatial evaluation of the design of middle-income housing units in .....

http://www.jchs.harvard.edu/sites/jchs.harvard.edu files/son 2013.pdf.

[3] Bahham, A. S. and Bahebil M. A., 2007. Analytical study of the design of housing units in housing projects in the Kingdom of Saudi Arabia , 7th Int'l Architectural Conference - Housing of the Poor Problems and Solutions - Assiut University, pp. 2-30 (in Arabic Language).

[4] Herbert. C, Hermann A, and McCue, D., 2018. Measuring Housing Affordability: Assessing the 30 Percent of Income Standard, the Joint Center for Housing Housing Studies of Harvard University.

https://www.jchs.harvard.edu/sites/default/files/Harvard_JCHS_Herbert_Hermann_McCue_mea suring_housing_affordability.pdf

[5] Al-Juhli, A., 2016. Providing affordable housing for low-income people in Yemen, Journal of Engineering Sciences, Assiut University, Vol. 44, No. 6, , pp. 703 - 725 (in Arabic Language).

[6] Abdul Latif, M. A. and Al-Furtaih, S. M., 2004. The difference in the concept of affordable housing and its impact on future housing development policies, Supreme Commission for the Development of Riyadh City Second Housing Symposium Facilitated Housing 21/3/2004, pp. 117-131 (in Arabic Language).

[7] Barashd, K. N. and Issa, A., 2008. Building Features of Yemen's Experience in Building Residential Neighborhoods for Low-Income Residents in the Suburbs, (Mukalla and Aden City Case Studies), Journal of Engineering Sciences, Assiut University,Vol.36,No.1, pp. 167- 187(in Arabic Language).

[8] Mubarak, S. M., 2009. Development of Degraded Urban Areas as a Method for Addressing Problems of Random Construction in the City of Aden, 2nd Engineering Conference - Aden University, pp. 201-214 (in Arabic Language).

[9] Itani, M. and Zahral-Din, R., 2017. Housing Policies in Yemen, Professional Master in Economic and Social Management Institute of Social Sciences, Lebanese University (in Arabic Language).

[10] Sager, A. T. M., 2011. Sager, A. T. M., 2012. The project of activating monitoring and urban follow-up for sustainable development in Arab cities, Concepts and Experiences of Urban Observatories, Quneitra - Urban Observatory Program - Arab Urban Development Institute - Kuwait. (in Arabic Language).

[11] Morgan, A., 2002. The role of state agencies in stimulating and activating the real estate market for low-income housing, Conference on activating the Egyptian real estate market, Al-Azhar University, Vol. 2, pp. 1-63 (in Arabic Language).

[12] Bramley, G and Karley, N K., 2005. How much extra affordable housing is needed in England?, Journal of Housing Studies Housing Studies, Vol. 20 , No. 5, pp. 685-715.

[13] Select Committee on Housing Affordability in Australia, 2008. A Good House is Hard to Find: Housing Affordability in Australia, The Senate, Commonwealth of Australia..

[14] Battellino, R., 2008. Background Notes for Opening Remarks to Senate Select Committee on Housing Affordability in Australia, Melbourne, 24 April 2008.

[15] Gabriel, M., Jacobs, K., Arthurson, K., Burke, T. and Yates, J., 2005. Conceptualizing and measuring the housing affordability problem, National Research Venture 3, Housing affordability for lower income Australians Research Paper No. 1, Australian Housing and Urban Research Institute.

[16] Mlligan, V., Phibbs, P., Gurran, N. and Fagan, K., 2007. Approaches to Evaluation of Affordable Housing Initiatives in Australia, Australian Housing and Urban Research Institute. Venture 3: Paper No. 7.

[17] Souza, L., 2005. Housing policy in North America and Europe, Institutional analysis and welfare state regimes American Real Estate Society Twenty - First ARES Annual Meeting Sante Fe, New Mexico.

[18] Ofori, G., 2011 . New Perspectives on Construction in Developing Countries, Abingdon: Spon Press, https://doi.org/10.4324/9780203847343.

[19] Alaghbari, W., Salim, A. and Dolla, K., 2008. Factors Influencing Low Cost Housing in Sana'a - Yemen, 2nd Int'l Conference on Built Environmental in Developing Countries (ICBEDC 2008), Universiti Sains Malaysia. 
[20] Liew, C., \& Haron, N. A. (2013), Factors Influencing the Rise of House Price in Klang Valley. International Journal of Research in Engineering and Technology, 2(10):261-272.

[21] Wendell, C., 2018. What is Middle-income Housing Affordability?, Publisher: Delore Zimmerman, 2018. Neogeograpgy.com.

http://www.newgeography.com/content/006007-what-middle-income-housing-affordability

[22] Wong, F. K. W., Hui, E. C. M. \& Ko, C. K., 2010. Factors affecting housing affordability and preferences of the elderly in Hong Kong. In 4th Australasian Housing Researchers Conference, 5-7 August 2009, Australia: APNHR. pp. 1-14.

[23] YING ,S. E., 2016 .FACTORS AFFECTING HOUSING AFFORDABILITY AMONG MIDDLE-INCOME HOUSEHOLD IN BINTULU, University College of Technology Sarawak.

[24] Taqeem Academy, 2016. Basic Principles of Real Estate Valuation, Saudi Commission for Accredited Residents, King Fahad Library Riyadh.

[25] Daniel, B, K., 2012. The Real Matrix (The American real estate society meetings) St. Petersburg, Florida 2012 , p.16.

[26] Henilane, I., 2016. HOUSING CONCEPT AND ANALYSIS OF HOUSING CLASSIFICATION. Baltic Journal of Real Estate Economics and Construction Management, Vol. 4 pp. 168-179

[27] https://www.bayut.com/mybayut/ar

[28] Enmaa Real Estate Development Company. 2013. Aden, Republic of Yemen: http://www.enma-ye.com/

[29] National Company for Real Estate Development. 2011. Mukalla, Republic of Yemen: http://www.wrdhome.com (in Arabic Language).

[30] Idris, M. A., 2004. Development of economic verification methods in housing, The Custodian of the Two Holy Mosque Institute Umm $\mathrm{Al}-$ Qura. researchgate.net/publication/310604692 (in Arabic Language). 
تقييم مكاني لتصميم الوحدات السكنية ذات الاخل المتوسط في مدينة عدن: دراسة حالة لمشروع الماءه السكني.

\author{
الملخص العربى
}

السكن حق اقتصادي واجتماعي وثقافي يجب أن يكون متاحًا في كل مسكن وهذه الحقوق نصت عليه الإن اليها

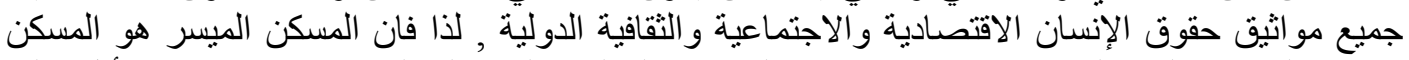

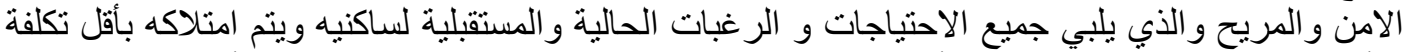
وبأفضل جودة ويمكن استخدامه بأفضل تكلفه والفي وان الوحدات الوات السكنية التي تحقق حدا أدنى من المعايير

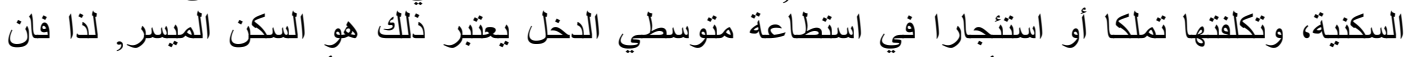

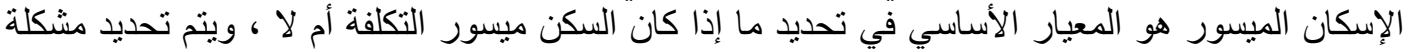

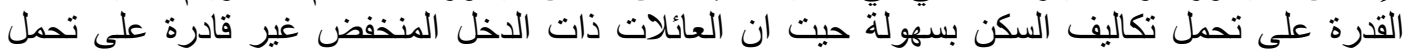

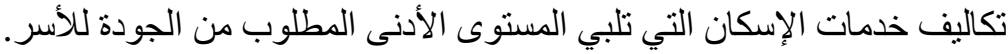

يهرف هذا البحث إلى در اسة مكونات الوحدات السكنية لبعض مشاريع ذوي الدخل المتوسط وتحليلها من

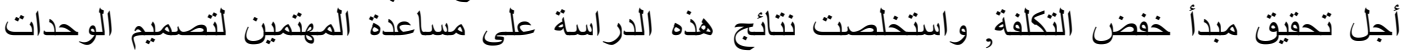

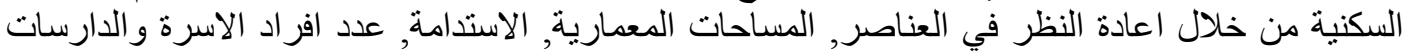

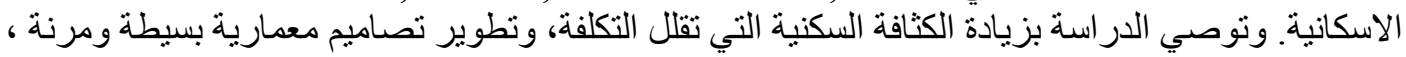
وخف تكاليف البناء ، وتوفير التمويل للإسكان و إعادة النظر في التشريعات الحالية في مجال الإسكان. كلمات مفتاحية :المسكن الميسر, الاسكان لمتوسطي الدخل, خفض التكلفة , بساطة التصميم ,الاستدامة, 